\title{
Acute effects of intravenous and rectal acetate on glucagon-like peptide-1, peptide YY, ghrelin, adiponectin and tumour necrosis factor- $\alpha$
}

\author{
Kristin R. Freeland ${ }^{1}$ and Thomas M. S. Wolever ${ }^{1,2 *}$ \\ ${ }^{1}$ Department of Nutritional Sciences, University of Toronto, Toronto, ON, Canada \\ ${ }^{2}$ St Michael's Hospital, Toronto, ON, Canada \\ (Received 18 February 2009 - Revised 4 August 2009 - Accepted 5 August 2009 - First published online 12 October 2009)
}

In animals, colonic infusion of SCFA does not affect glucagon-like peptide-1 (GLP-1) release whereas intravenous infusion does and SCFA may directly stimulate peptide YY (PYY) release. It is unknown whether SCFA and their route of administration affect human blood concentrations of GLP-1 and PYY. Our aim was to conduct a pilot study to determine the effects of intravenous and rectal acetate on blood concentrations of GLP-1, PYY, ghrelin, adiponectin and TNF- $\alpha$ in hyperinsulinaemic human subjects. Six hyperinsulinaemic female subjects were given 20 mmol sodium acetate intravenously, $60 \mathrm{mmol}$ acetate rectally, or normal saline rectally or intravenously on four separate occasions in randomised order, with blood samples collected at 0,10,15,30, 45 and $60 \mathrm{~min}$. Change in plasma PYY was significantly higher after acetate and rectal infusions $(9.69$ and $13.78 \mathrm{pg} / \mathrm{ml})$ compared with saline and intravenous $(0.60$ and $-3.1 \mathrm{pg} / \mathrm{ml} ; P<0.01)$, respectively. Change in plasma GLP-1 was increased by rectal and acetate infusions $(0.25$ and $0.23 \mathrm{mmol} / \mathrm{l}) v$. intravenous and saline $(-0.26$ and $-0.19 \mathrm{mmol} / \mathrm{l} ; P<0 \cdot 01)$. Acetate decreased TNF- $\alpha v$. saline $(-0.8$ and $0.15 \mathrm{pg} / \mathrm{ml} ; P<0.05)$. Rectal infusions increased TNF- $\alpha$ and ghrelin $(0.2$ and $98.27 \mathrm{pg} / \mathrm{ml}) v$. intravenous $(-0.9$ and $-40 \mathrm{pg} / \mathrm{ml} ; P<0.01)$. There was no effect of treatment on plasma adiponectin. These preliminary results suggest that acetate raises plasma PYY and GLP-1, and suppresses TNF- $\alpha$. Also, distending the rectum increases PYY, GLP-1, TNF- $\alpha$ and ghrelin in hyperinsulinaemic females. Increasing colonic fermentation products, particularly acetate, could yield a new mechanism for modifying weight gain.

Acetate: Infusion: Hormones

High intake of dietary fibre is associated with reduced weight gain $^{(1)}$ and reduced risk for CVD and type 2 diabetes ${ }^{(2-5)}$. These effects may be due partly to the effects of increased colonic fermentation on gut- and adipose-derived hormones. Glucagon-like peptide-1 (GLP-1) and peptide YY (PYY) are gut hormones involved in the regulation of appetite ${ }^{(6-8)}$. Animal and cell-culture studies suggest that colonic distension or the SCFA products of fermentation may up-regulate PYY and proglucagon gene expression ${ }^{(9)}$ and stimulate PYY and GLP-1 release ${ }^{(10)}$. In addition to its effects on appetite regulation, GLP-1 may also protect against type 2 diabetes by increasing insulin secretion and sensitivity and preserving the mass of insulin-secreting $\beta$-cells in the pancreas ${ }^{(11,12)}$. Adiponectin and TNF- $\alpha$ are hormones produced by adipose tissue which may influence the risk of type 2 diabetes and CVD via effects on insulin sensitivity and endothelial function ${ }^{(13,14)}$.

The effect of SCFA on gut and adipose hormones may differ in different animal species and may depend on whether SCFA are infused intravenously (IV) or rectally ${ }^{(9,10)}$. The effects in human subjects are not known. Since acetate is the major SCFA produced during colonic fermentation, our objectives were to conduct a pilot study to compare the effects of IV $v$. rectal infusion of sodium acetate $v$. sodium chloride (normal saline) on blood concentrations of GLP-1,
PYY, ghrelin, adiponectin and TNF- $\alpha$ in hyperinsulinaemic human subjects. We studied hyperinsulinaemic subjects because, being at increased risk for obesity, type 2 diabetes and CVD, they could stand to benefit from any protective effects of increased fibre intake.

\section{Subjects and methods}

Subjects

Six females (age 44 (SEM 4) years; BMI $31.0($ SEM 1.0$) \mathrm{kg} / \mathrm{m}^{2}$ ) with high fasting plasma insulin (105 (SEM 19) pmol/l) were recruited from Toronto and the surrounding area. Subjects were excluded from the study if they were pregnant, had a history of endocrine or gastrointestinal problems, diabetes, recent surgery, or had taken antibiotics within the previous 3 months. All but one of the subjects were participants in a previous study. The present study was conducted according to the guidelines laid down in the Declaration of Helsinki and all procedures involving human subjects were approved by the Human Subjects Review Committee, Office of Research Services, St Michael's Hospital and University of Toronto. Written informed consent was obtained from all subjects.

Abbreviations: CGRP, calcitonin gene-related peptide; GLP-1, glucagon-like peptide-1; IV, intravenous; PPY, peptide YY.

* Corresponding author: Dr T. M. S. Wolever, fax +1 416971 3130, email thomas.wolever@utoronto.ca 


\section{Study design}

The study followed a single-blind, randomised cross-over design where subjects were infused IV and rectally with sodium acetate or saline on four different occasions. The four treatments consisted of (a) $20 \mathrm{mmol}$ sodium acetate $(1.66 \mathrm{~g})$ dissolved in $100 \mathrm{ml}$ sterile water given IV; (b) $100 \mathrm{ml}$ saline given IV; (c) $60 \mathrm{mmol}$ sodium acetate $(4.92 \mathrm{~g})$ dissolved in $300 \mathrm{ml}$ water given rectally; (d) $300 \mathrm{ml}$ water given rectally. The IV infusions were performed manually by a physician at a rate of $12.5 \mathrm{ml}$ per min. The rectal infusions were also performed manually by the research coordinator at a rate of $37.5 \mathrm{ml}$ per min using five $60 \mathrm{ml}$ syringes. For the rectal infusions approximately $2 \mathrm{~cm}$ of the end of a piece of Tygon tubing (outer diameter $4 \mathrm{~mm}$; Norton Performance Plastics, Akron, OH, USA) was inserted in subjects' rectums. The other end of tubing was connected to a three-way tap and the dispensing syringe. The treatments were prepared by the Pharmacy at St Michael's Hospital on the morning they were required.

Subjects came to the Nutrition Centre at St Michael's Hospital at about 08.00 hours after a $12 \mathrm{~h}$ overnight fast on four separate occasions approximately 1 week apart. Upon arrival, an IV catheter was inserted into an arm vein for blood taking and a fasting blood sample obtained. The IV infusions were given via the same catheter at a rate of $12.5 \mathrm{ml}$ per min over $8 \mathrm{~min}$; after the test solution had been infused the catheter was flushed with $20 \mathrm{ml}$ normal saline. For the rectal infusions, subjects inserted the plastic tubing into the rectum and the treatments were administered using a syringe at a rate of $37.5 \mathrm{ml}$ per min for $8 \mathrm{~min}$. Blood samples for glucose, insulin, hormones and acetate were collected fasting and at 10, 15, 30, 45 and $60 \mathrm{~min}$ after the start of the infusion.

\section{Blood samples for plasma acetate concentrations}

Blood was collected into tubes with potassium oxalate and centrifuged at $600 \mathrm{~g}$ for $10 \mathrm{~min}$ at $4^{\circ} \mathrm{C}$. The plasma was removed and stored at $-70^{\circ} \mathrm{C}$ until sample preparation and analysis by GC as previously described ${ }^{(15)}$.

\section{Blood samples for plasma glucose and insulin}

Blood was collected into Vacutainer ${ }^{\mathrm{TM}} \operatorname{SST}^{\mathrm{TM}}$ (BD Canada, Mississauga, ON, Canada) tubes. Insulin inhibitor (50 $\mu \mathrm{l}$; Banting and Best Diabetes Centre, Mount Sinai Hospital, Toronto, ON, Canada) was added immediately. The samples were mixed and centrifuged at $600 \mathrm{~g}$ for $10 \mathrm{~min}$ at $4^{\circ} \mathrm{C}$ and the plasma removed and stored at $-70^{\circ} \mathrm{C}$ until analysis of glucose using a enzymic reference method with hexokinase ${ }^{(16)}$ and insulin by electrochemiluminescence immunoassay ${ }^{(17)}$.

\section{Blood samples for plasma glucagon-like peptide-1 and peptide $Y Y$}

Blood was collected into ice-cooled EDTA tubes. Then $50 \mu \mathrm{l}$ each of dipeptidyl peptidase-IV inhibitor (Millipore, Billerica, MA, USA) and aprotinin (Trasylol ${ }^{\circledR}$; Bayer Inc., Toronto, ON, Canada) were added and mixed within $30 \mathrm{~s}$ of collection. The samples were centrifuged at $300 \mathrm{~g}$ for $15 \mathrm{~min}$ at $4^{\circ} \mathrm{C}$ and the plasma removed and stored at $-70^{\circ} \mathrm{C}$ until analysis. GLP-1 was analysed by ELISA (Millipore) at the Banting and Best Diabetes Centre. This is a procedure that captures active GLP-1 (7-36amide and 7-37) by a monoclonal antibody with specific binding to the N-terminal region of the molecule. PYY was measured in quadruplicate by a commercially available RIA (Millipore), using ${ }^{125}$ I-labelled bioactive PYY as a tracer and $\mathrm{PYY}_{3-36}$ antibody raised in guinea-pigs. This procedure captures human $\mathrm{PYY}_{3-36}$ with an intra- and inter-assay CV of 6.5 and $7.5 \%$.

\section{Blood samples for plasma adiponectin and TNF- $\alpha$}

Blood was collected into ice-cooled EDTA tubes. The samples were centrifuged at $300 \mathrm{~g}$ for $15 \mathrm{~min}$ at $4^{\circ} \mathrm{C}$ and the plasma was removed and stored at $-70^{\circ} \mathrm{C}$ until analysis. Adiponectin was analysed in duplicate by RIA (Millipore), using ${ }^{125}$ I-labelled murine adiponectin as a tracer and a multispecies adiponectin rabbit antibody. Intra- and inter-assay $\mathrm{CV}$ were 4.5 and $8.1 \%$. TNF- $\alpha$ was analysed by the sandwich enzyme immunoassay technique ${ }^{(18)}$ at the Banting and Best Diabetes Centre.

\section{Blood samples for plasma ghrelin}

Blood was collected into ice-cooled EDTA tubes and $50 \mu \mathrm{l}$ aprotinin (Trasylol ${ }^{\circledR}$; Bayer Inc.) was added immediately. The samples were then mixed and centrifuged at $300 \mathrm{~g}$ for $15 \mathrm{~min}$ at $4^{\circ} \mathrm{C}$, and $5 \mathrm{M}-\mathrm{HCl}(200 \mu \mathrm{l})$ was added to the plasma for a final concentration of $0.05 \mathrm{M}$. The plasma was removed and stored at $-70^{\circ} \mathrm{C}$ until analysis. Active ghrelin was analysed in quadruplicate by a commercially available RIA (Millipore), using ${ }^{125}$ I-labelled bioactive ghrelin as a tracer and a polyclonal antibody raised in rabbits against the C-terminal end of human ghrelin. Intra- and inter-assay CV were 8.5 and $13.2 \%$.

\section{Statistical analysis}

The elimination rate constant for acetate (Kac) was the regression slope of the exponential fitted to the disappearance curve of acetate after the end of the IV infusion (10-60 min). The plasma half-time was calculated as $0.693 / \mathrm{Kac}$. The change from baseline for all variables was calculated by subtracting the concentration at baseline (time 0 ) from that at every other time. Differences in plasma concentrations of acetate, glucose, insulin and hormones were assessed by repeatedmeasures ANOVA for the main effects of acetate (acetate $v$. saline), route (IV $v$. rectal) and time and their interactions. If there was no significant interaction between acetate, route and time, the data were analysed as a two-factor ANOVA with repeated measures on route and acetate. Differences in plasma concentrations between the four treatments were assessed as a secondary analysis by two-factor ANOVA with repeated measures on time and treatment; if there was a significant time $\times$ treatment interaction ANOVA was performed at each time point. For all analyses, individual means were compared using Tukey's test to correct for multiple comparisons with the criterion for significance being (two-tailed) $P<0 \cdot 05$. The analyses were not adjusted for multiple endpoints. All statistical analyses were performed 
by version 9.1 of SAS (SAS Institute Inc., Cary, NC, USA). Results are expressed as mean values with their standard errors.

\section{Results}

All subjects completed the four treatments. Fasting plasma acetate, glucose and hormone concentrations did not differ significantly between treatments (Table 1).

\section{Acetate, glucose and insulin}

There were significant main effects of route $(P<0.01)$ and acetate $(P<0.0001)$ and significant route $\times$ acetate $\times$ time $(P<0.0001)$ and route $\times$ acetate $(P<0.025)$ interactions, for plasma acetate (Table 2). Plasma acetate was significantly greater after IV acetate than all other treatments at $10 \mathrm{~min}$ and significantly greater after IV acetate than IV saline and rectal saline at $15 \mathrm{~min}$. From 30 to $60 \mathrm{~min}$ plasma acetate was significantly greater after rectal acetate than after all other treatments (Fig. 1). After IV acetate the elimination rate constant was 0.33 (SEM 0.03) per min with a serum half-life of 2.2 (SEM 0.2 ) $\mathrm{min}$. There were no significant effects for either plasma glucose or insulin (Table 2, Fig. 2).

\section{Glucagon-like peptide-1}

Plasma GLP-1 was significantly higher after rectal than IV infusions and significantly higher after acetate than saline infusions (significant main effects of route and acetate; Table 2). When comparing the IV and rectal acetate infusions, IV infusions increased plasma GLP-1 to a significantly greater extent than rectal infusions (route $\times$ acetate interaction; $P=0 \cdot 01$ ), but no significant differences were found at the individual time points (Fig. 3(a)).

\section{Peptide $Y Y$}

For PYY, there were significant main effects of time $(P<0.025)$, route $(P<0.001)$ and acetate $(P<0.001)$, and a significant time $\times$ acetate interaction $(P<0.05)$ (Table 2). Plasma PYY was significantly higher after rectal than IV infusions and significantly higher after acetate than saline.
At $10 \mathrm{~min}$, plasma PYY was significantly greater after rectal saline than IV saline. After rectal acetate, plasma PYY continued to increase throughout the experiment, being significantly higher than IV saline at 15 and $30 \mathrm{~min}$, higher than IV acetate and IV saline at $45 \mathrm{~min}$, and higher than all other treatments at $60 \mathrm{~min}$ (time $\times$ treatment interaction; $P<0 \cdot 001$; Fig. 3(b)).

\section{Ghrelin}

There was no effect of treatment on plasma ghrelin concentrations (Fig. 3(c)). Plasma ghrelin was significantly higher after rectal than IV infusions (main effect of route; $P<0 \cdot 01$ ) but the main effect of acetate was not significant $(P=0 \cdot 07$; Table 2). Plasma ghrelin tended to be highest after rectal saline infusion (Fig. 3(c)), but the route $\times$ acetate interaction was not significant.

\section{$T N F-\alpha$ and adiponectin}

There were significant main effects of route $(P<0.05)$ and acetate $(P<0.05)$, such that plasma TNF- $\alpha$ was higher after rectal than IV infusions and after saline than acetate (Table 2); there was no significant route $\times$ acetate interaction (Fig. 3(d)). Plasma adiponectin concentrations were not affected by treatment, route or acetate (Table 2).

\section{Discussion}

Increased colonic fermentation may influence gut and adipose hormones by distending the colon or by increasing serum SCFA concentrations. Our preliminary results suggest that both these effects may acutely stimulate PYY and GLP-1 secretion in human subjects. Furthermore, raising serum acetate acutely suppressed TNF- $\alpha$ while distending the rectum raised plasma TNF- $\alpha$ and ghrelin concentrations.

It has been estimated that $220-760 \mathrm{mmol}$ SCFA are produced daily from the colonic fermentation of malabsorbed starch and dietary fibre, depending on the types of carbohydrate foods in the diet ${ }^{(19)}$. Since acetate, propionate and butyrate exist in human colonic contents in molar ratios of

Table 1. Fasting values for metabolic parameters by treatment (Mean values with their standard errors)

\begin{tabular}{|c|c|c|c|c|c|c|c|c|c|}
\hline \multirow[b]{3}{*}{ Variable } & \multicolumn{8}{|c|}{ Treatments* } & \multirow[b]{3}{*}{$P$} \\
\hline & \multicolumn{2}{|c|}{ I-S } & \multicolumn{2}{|c|}{ I-A } & \multicolumn{2}{|c|}{ R-S } & \multicolumn{2}{|c|}{ R-A } & \\
\hline & Mean & SEM & Mean & SEM & Mean & SEM & Mean & SEM & \\
\hline Acetate $(\mu \mathrm{mol} / \mathrm{l})$ & $27 \cdot 3$ & $5 \cdot 2$ & $25 \cdot 9$ & $6 \cdot 0$ & $26 \cdot 0$ & $7 \cdot 2$ & $17 \cdot 8$ & $3 \cdot 3$ & 0.48 \\
\hline Glucose (mmol/l/) & 4.50 & 0.2 & 4.73 & 0.3 & 4.55 & 0.1 & 4.53 & 0.2 & 0.26 \\
\hline Insulin (pmol/l) & 104 & 40 & 106 & 43 & $80 \cdot 0$ & $9 \cdot 8$ & 121 & 50 & 0.51 \\
\hline GLP-1 (pmol/l) & 3.50 & 0.7 & $4 \cdot 2$ & $1 \cdot 1$ & $2 \cdot 83$ & 0.5 & 3.50 & 0.7 & 0.69 \\
\hline PYY (pg/ml) & $86 \cdot 4$ & $7 \cdot 3$ & 83.7 & 17 & $95 \cdot 3$ & 13 & $86 \cdot 3$ & 13 & 0.90 \\
\hline Ghrelin (pg/ml) & 181 & 68 & 274 & 158 & 166 & 105 & 150 & 45 & 0.82 \\
\hline Adiponectin $(\mathrm{pg} / \mathrm{ml})$ & $10 \cdot 4$ & 1.4 & $12 \cdot 0$ & 3.7 & $10 \cdot 7$ & 1.9 & $12 \cdot 0$ & 1.6 & 0.39 \\
\hline TNF- $\alpha(\mathrm{pg} / \mathrm{ml})$ & 1.93 & 0.4 & 2.53 & 1.7 & 0.77 & 0.5 & $2 \cdot 68$ & 1.3 & 0.62 \\
\hline
\end{tabular}

I-S, intravenous saline; I-A, intravenous acetate; R-S, rectal saline; R-A, rectal acetate; GLP-1, glucagon-like peptide-1; PPY, peptide YY ${ }^{*}$ For details of the four treatments, see Subjects and methods, study design section. 


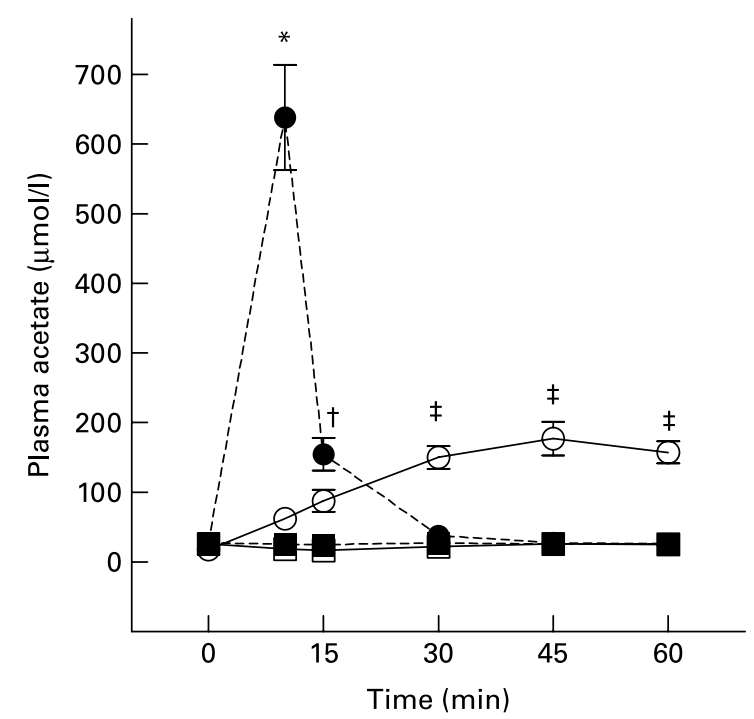

Fig. 1. Plasma acetate concentrations in six subjects who were given intravenous (IV) acetate (--0--), rectal acetate (-O-), IV saline (--口--) or rectal saline (- $\square-)$. Values are means, with standard errors represented by vertical bars. There was a time $\times$ treatment interaction $(P<0.0001)$. *IV acetate $>$ rectal acetate, IV saline and rectal saline $(P<0.01$; Tukey corrected; ANOVA). †IV acetate $>$ IV saline and rectal saline $(P<0.05$; Tukey corrected; ANOVA). $\ddagger$ Rectal acetate $>$ IV acetate, IV saline and rectal saline $(P<0.025$; Tukey corrected; ANOVA).

about $3: 1: 1^{(20)}$, the amount of acetate produced would be expected to be in the range of $130-460 \mathrm{mmol} / 24 \mathrm{~h}$; thus, $20 \mathrm{mmol}$ acetate, the amount we infused IV, would be produced within $1-4 \mathrm{~h}$. We infused $60 \mathrm{mmol}$ acetate rectally because we found that $25-30 \%$ of rectal acetate is absorbed into the circulation over $30 \mathrm{~min}^{(15)}$.

After rectal acetate infusion, serum acetate reached a peak at about $45 \mathrm{~min}$; this is consistent with previous studies in human subjects in which serum acetate peaked between 60 and $90 \mathrm{~min}$ after rectal infusion of $180 \mathrm{mmol}$ acetate over $30 \mathrm{~min}$, and between 30 and $60 \mathrm{~min}$ after rectal infusion of $90 \mathrm{mmol}$ acetate over $30 \mathrm{~min}^{(21,22)}$. However, the elimination rate constant of serum acetate after IV acetate infusion was over ten times that previously reported in normal subjects ${ }^{(23)}$. This difference may be explained by differences in infusion protocol and analytical methods. In the previous study, acetate clearance may have been delayed because it was infused at a
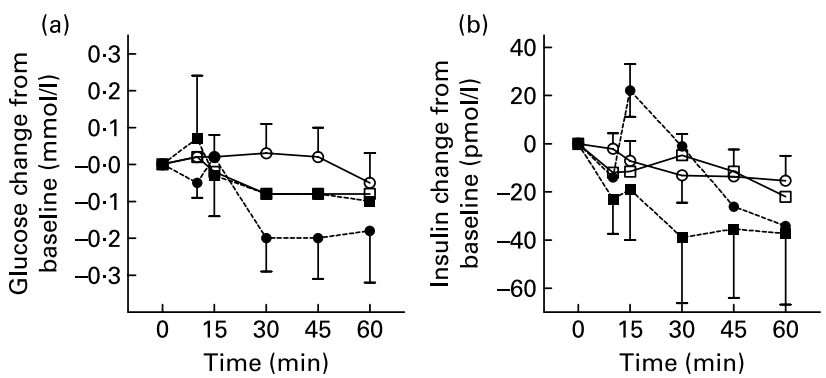

Fig. 2. Change in plasma concentrations of (a) glucose and (b) insulin in six subjects who were given intravenous (IV) acetate (--0--), rectal acetate $(-\bigcirc-)$, IV saline (-- ---) or rectal saline $(-\square-)$. Values are means, with standard errors represented by vertical bars. There were no significant differences between treatments by ANOVA. 

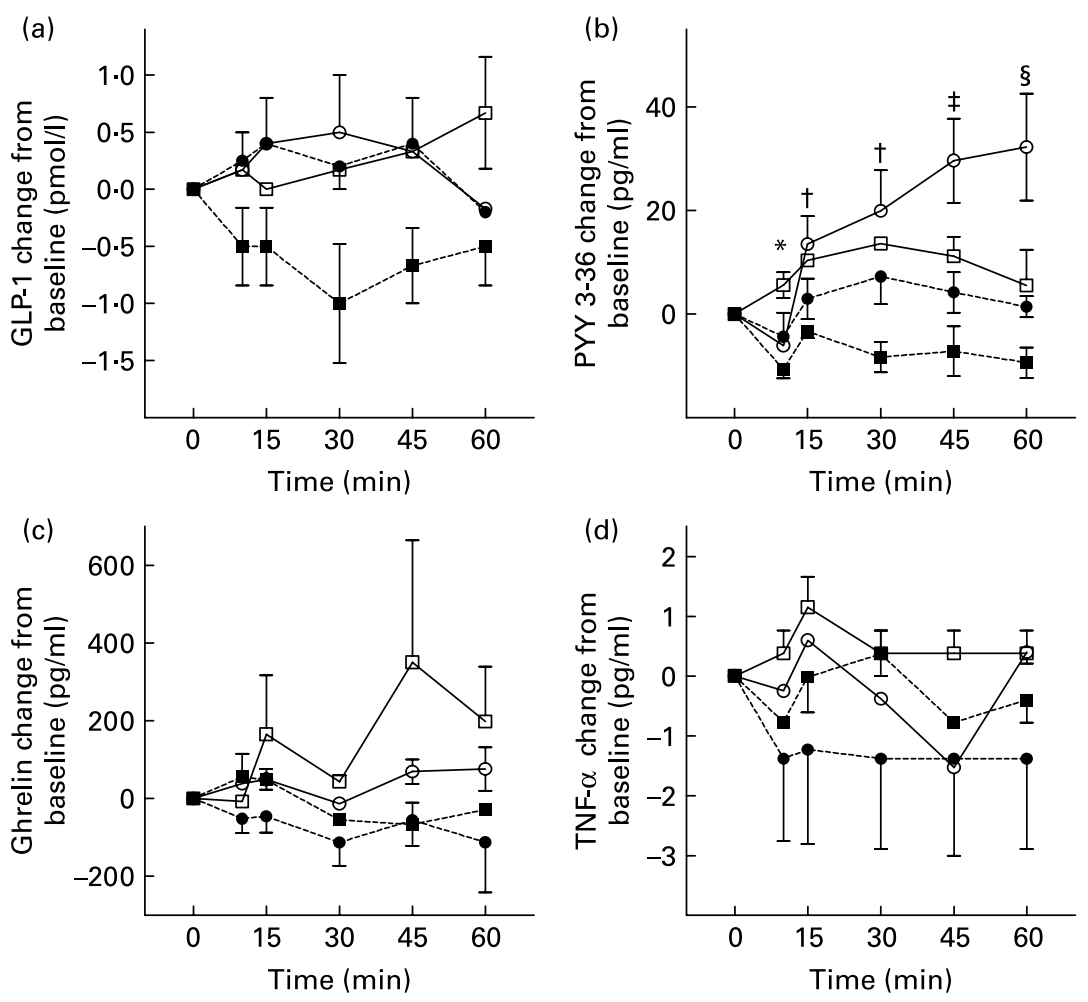

Fig. 3. Change in plasma (a) glucagon-like peptide-1 (GLP-1), (b) peptide YY (PYY), (c) ghrelin and (d) TNF- $\alpha$ in six subjects who were given intravenous (IV)

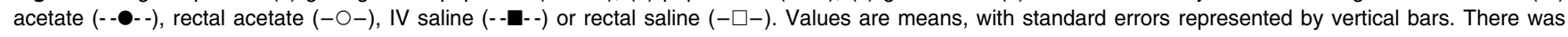
a time $\times$ treatment interaction for PYY $(P<0.001)$; (ANOVA). ${ }^{*}$ Rectal saline $>$ IV saline $(P<0.025$; Tukey corrected). $\dagger$ Rectal acetate $>$ IV saline $(P<0.02$; Tukey corrected). $¥$ Rectal acetate $>$ IV acetate and IV saline $(P<0.01$; Tukey corrected). $\S$ Rectal acetate $>$ IV acetate, IV saline and rectal saline $(P<0.001$; Tukey corrected).

rate of $2.5 \mathrm{mmol} / \mathrm{min}$ for $60 \mathrm{~min}$ instead of only $8 \mathrm{~min}$ in the present study. In addition, serum acetate was measured using an enzymic method which resulted in nearly 10 -fold higher fasting values (220 (SEM 10) v. 24 (SEM 4) $\mu \mathrm{mol} / \mathrm{l}$ ) but less than 2-fold higher peak values than those we obtained (1120 (SEM 20) v. 637 (SEM 62) $\mu \mathrm{mol} / \mathrm{l}$ ).

The lack of effect of acetate on plasma glucose and insulin is consistent with previous $\mathrm{IV}^{(23)}$ and rectal infusion studies ${ }^{(21)}$ and also in keeping with its lack of effect on glucose tolerance and glucose turnover in healthy subjects ${ }^{(24,25)}$.

We found that both raising serum acetate and distending the rectum significantly raised plasma GLP-1 levels. This is not consistent with a previous report that failed to show an effect on plasma GLP-1 of rectal infusion of 54 or $90 \mathrm{mmol}$ SCFA (37.8 and $63 \mathrm{mmol}$ acetate, respectively) ${ }^{(26)}$. However, we infused $300 \mathrm{ml}$ fluid into the rectum over $8 \mathrm{~min}$ whereas Ropert et al. ${ }^{(26)}$ infused $180 \mathrm{ml}$ over $1 \mathrm{~h}(3 \mathrm{ml} / \mathrm{min})$ into the proximal colon. Therefore our infusion rate probably produced a higher rise in serum acetate and greater colonic distension. The effect of acetate may be mediated via calcitonin generelated peptide (CGRP). Acetate (1 mM) increases CGRP secretion from the rat colon ${ }^{(27)}$, and CGRP, in turn, increases GLP-1 release from rat ileum ${ }^{(28,29)}$. There may also be a direct effect of SCFA on GLP-1 secretion, since addition of SCFA to total parenteral nutrition feeding for periods of 6 to $72 \mathrm{~h}$ increased ileal proglucagon mRNA in rats ${ }^{(30,31)}$, an effect which is not butyrate specific ${ }^{(32)}$. The mechanism by which rectal distension increases GLP-1 is not clear; nevertheless, ileal infusion of saline increased GLP-1 from baseline in pigs ${ }^{(10)}$.

Similar to GLP-1, PYY is produced and secreted from intestinal L-cells located primarily in the distal ileum and proximal colon. Expression of the SCFA receptor G-protein coupled receptor 43 has been found in enteroendocrine L-cells containing PYY in the rat intestine and human colon ${ }^{(33)}$. Furthermore, CGRP $^{(28)}$ and SCFA ${ }^{(34)}$ both increased PYY release from the isolated vascularly perfused rat ileum. Consistent with these results, in the present study infusion of acetate into the rectum elicited a gradual and sustained release of PYY. The less pronounced and transient rise in PYY seen after IV infusion of acetate is also consistent with this mechanism since less acetate would reach the gut and for a shorter period of time. Similar to previous studies ${ }^{(10,26,35)}$, rectal saline infusion also elicited a transient rise in PYY, suggesting that mechanical distension of the rectum stimulates PYY secretion as well.

Ghrelin is an orexigenic factor released primarily from oxyntic cells of the stomach, but also from the duodenum, ileum, caecum and colon ${ }^{(36,37)}$. Ingestion of carbohydrate and fat decreases plasma ghrelin in human subjects, whereas ingestion of protein increases postprandial ghrelin ${ }^{(38)}$. We found that acetate tended to reduce ghrelin relative to saline but this effect did not reach statistical significance. It is of interest that distending the rectum with the rectal infusions increased plasma ghrelin significantly compared with IV infusions. This may have been due to mechanical stimulation of 
the colon or neuronal signalling to the stomach, since the greatest concentration of oxyntic cells is in the stomach. By contrast, distension of the stomach with a solution of guar gum had no effect on plasma ghrelin ${ }^{(38)}$.

Adiponectin levels are decreased in obesity-related insulin resistance ${ }^{(13)}$ and this may be due, at least in part, to increased TNF- $\alpha^{(14)}$. Chronic elevation of TNF- $\alpha$, and other inflammatory markers, leads to insulin resistance whereas adiponectin promotes insulin sensitivity ${ }^{(13)}$. Both adiponectin and TNF- $\alpha$ are produced and secreted by adipose tissue. In response to adipogenesis, TNF- $\alpha$ and TNF receptor 2 are decreased ${ }^{(39)}$ and acetate is an agonist of adipogenesis ${ }^{(40)}$. However, we did not see any changes in plasma concentrations of adiponectin with acetate administration regardless of the route. Acetate decreased TNF- $\alpha$ compared with saline, consistent with increased adipogenesis, and rectal infusion increased TNF- $\alpha$ compared with IV. Similar to ghrelin, this may have been due to mechanical stimulation of the colon; the relative swiftness of its distension may have induced a slight stress response.

Previously we have shown that long-term ingestion of wheat fibre increases plasma levels of butyrate and acetate ${ }^{(41)}$ and others have shown increases in faecal bulk and stool weight $^{(42)}$. Based on our current findings, both of these effects would be expected to raise GLP-1 and PYY, indeed as we have shown for GLP-1 ${ }^{(41)}$. This would be of benefit, particularly for obesity, since both reduce food intake ${ }^{(6-8)}$. Conversely, increased colonic fermentation with fibre intake may lower, whereas faecal bulking may raise $\mathrm{TNF}-\alpha$ and ghrelin. Thus, there may be no overall effect of increased cereal fibre intake on these hormones.

The plasma acetate concentrations achieved after rectal infusion were within an achievable range. Previous research has shown that fasting plasma concentrations of acetate can rise to $100-300 \mu \mathrm{mol} / \mathrm{l}$ after ingestion of fermentable carbohydrate ${ }^{(43,44)}$. In the present study, peak plasma acetate levels were about $200 \mu \mathrm{mol} / \mathrm{l}$ after rectal infusion of acetate. By contrast, IV acetate resulted in peak plasma acetate concentrations of about $650 \mu \mathrm{mol} / \mathrm{l}$. We gave acetate as a bolus to achieve as high a blood value as possible and determine if there was an effect. However, continuous infusion of acetate would probably be more appropriate to imitate the physiological production and absorption of acetate.

We conclude that both distending the rectum and infusing acetate acutely raised plasma PYY and GLP-1 in hyperinsulinaemic, overweight women. Furthermore, acetate suppressed TNF- $\alpha$ and distending the rectum increased TNF- $\alpha$ and ghrelin. These findings may be relevant to our understanding of the effect of dietary fibre on weight management and insulin sensitivity. However, it is important to note that our conclusions apply to the acute infusion of acetate; it is possible that the responses may vary with long-term ingestion of cereal fibre due to adaptation of colonic bacteria. With chronic ingestion of cereal fibre, plasma SCFA, particularly butyrate, and GLP-1 gradually rose over time ${ }^{(41)}$, but plasma acetate did not reach levels seen in the present study. Thus, whether the other hormone levels would change to the same extent with increased cereal fibre warrants investigation. In addition, because of the small number of subjects studied, further work is required to confirm these effects.

\section{Acknowledgements}

The present study was supported by Canadian Institutes of Health Research (CIHR) Institute of Nutrition, Metabolism and Diabetes operating grant OOP-64648.

K. R. F. conducted the research and wrote the manuscript under the supervision of T. M. S. W.

There are no conflicts of interest for either author.

\section{References}

1. Ludwig DS, Pereira MA, Kroenke CH, et al. (1999) Dietary fiber, weight gain, and cardiovascular risk factors in young adults. JAMA 282, 1539-1546.

2. Liu S, Stampfer MJ, Hu FB, et al. (1999) Whole-grain consumption and risk of coronary heart disease: results from the Nurses' Health Study. Am J Clin Nutr 70, 412-419.

3. Wolk A, Manson JE, Stampfer MJ, et al. (1999) Long-term intake of dietary fiber and decreased risk of coronary heart disease among women. JAMA 281, 1998-2004.

4. Salmeron J, Ascherio A, Rimm EB, et al. (1997) Dietary fiber, glycaemic load, and risk of NIDDM in men. Diabetes Care 20 , 545-550.

5. Meyer KA, Kushi LH, Jacobs DR Jr, et al. (2000) Carbohydrates, dietary fiber, and incident type 2 diabetes in older women. Am J Clin Nutr 71, 921-930.

6. Flint A, Raben A, Astrup A, et al. (1998) Glucagon-like peptide-1 promotes satiety and suppresses food intake in humans. J Clin Invest 101, 515-520.

7. Batterham RL, Cowley MA, Small CJ, et al. (2002) Gut hormone $\mathrm{PYY}_{3-36}$ physiologically inhibits food intake. Nature 418, 650-654.

8. Batterham RL, Cohen MA, Ellis SM, et al. (2003) Inhibition of food intake in obese subjects by peptide $\mathrm{YY}_{3-36}$. NEJM 349, 941-948.

9. Zhou J, Hegsted M, McCutcheon KL, et al. (2006) Peptide YY and proglucagon mRNA expression patterns and regulation in the gut. Obesity 14, 683-689.

10. Cuche G, Cuber JC \& Malbert CH (2000) Ileal short-chain fatty acids inhibit gastric motility by a humoral pathway. Am J Physiol Gastrointest Liver Physiol 279, G925-G930.

11. MacDonald PE, El-Kholy W, Riedel MJ, et al. (2002) The multiple actions of GLP-1 on the process of glucose-stimulated insulin secretion. Diabetes 51, Suppl. 3, S434-S442.

12. Farilla L, Bulotta A, Hirshberg B, et al. (2003) Glucagon-like peptide 1 inhibits cell apoptosis and improves glucose responsiveness of freshly isolated human islets. Endocrinology 144, 5149-5158.

13. Bastard JP, Maachi M, Lagathu C, et al. (2006) Recent advances in the relationship between obesity, inflammation, and insulin resistance. Eur Cytokine Network 17, 4-12.

14. Stern N, Osher E \& Greenman Y (2007) Hypoadiponectinemia as a marker of adipocyte dysfunction - Part II: The functional significance of low adiponectin secretion. J Cardiometab Syndrome 2, 288-294.

15. Vogt JA \& Wolever TMS (2003) Fecal acetate is inversely related to acetate absorption from the human rectum and distal colon. J Nutr 133, 3145-3148.

16. Banting and Best Diabetes Centre (2003) BBDC Laboratories method for analysis of glucose. Version current 2 December 2003. http://www.bbdc.org/laboratories/9.htm (last accessed November 2007).

17. Banting and Best Diabetes Centre (2003) BBDC Laboratories method for analysis of insulin. Version current 2 December 2003. http://www.bbdc.org/laboratories/1.htm (last accessed November 2007). 
18. Banting and Best Diabetes Centre (2003) BBDC Laboratories method for analysis of tumor necrosis factor- $\alpha$ (TNF- $\alpha$ ) human. Version current 2 December 2003. http://www.bbdc. org/laboratories/8.htm (last accessed November 2007).

19. McBurney MI, Thompson LU, Cuff DJ, et al. (1988) Comparison of ileal effluents, dietary fibers and whole foods in predicting the physiological importance of colonic fermentation. Am J Gastroenterol 83, 536-540.

20. Cummings JH, Pomare EW, Branch WJ, et al. (1987) Short chain fatty acids in human large intestine, portal, hepatic and venous blood. Gut 28, 1221-1227.

21. Wolever TM, Spadafora P \& Eshuis H (1991) Interaction between colonic acetate and propionate in humans. Am J Clin Nutr 53, 681-687.

22. Wolever TMS, Brighenti F \& Jenkins DJA (1988) Serum short chain fatty acids after rectal infusion of acetate and propionate in man. J Clin Nutr Gastroenterol 3, 42-46.

23. Akanji AO \& Hockaday TDR (1990) Acetate tolerance and the kinetics of acetate utilization in diabetic and nondiabetic subjects. Am J Clin Nutr 51, 112-118.

24. Scheppach W, Cummings JH, Branch WH, et al. (1988) Effect of gut-derived acetate on oral glucose tolerance in man. Clin Sci 75, 355-361.

25. Scheppach W, Wiggins HS, Halliday D, et al. (1988) Effect of gut-derived acetate on glucose turnover in man. Clin Sci $\mathbf{7 5}$ $363-370$

26. Ropert A, Cherbut C, Rozé C, et al. (1996) Colonic fermentation and proximal gastric tone in humans. Gastroenterology 111, 289-296.

27. Grider JR \& Piland BE (2007) The peristaltic reflex induced by short-chain fatty acids is mediated by sequential release of 5-HT and neuronal CGRP but not BDNF. Am J Physiol Gastrointest Liver Physiol 292, G429-G437.

28. Dumoulin V, Dakka T, Plaisancie P, et al. (1995) Regulation of glucagon-like peptide-1-(7-36) amide, peptide YY, and neurotensin secretion by neurotransmitters and gut hormones in the isolated vascularly perfused rat ileum. Endocrinology 136, $5182-5188$.

29. Herrmann-Rinke C, McGregor GP \& Göke B (2000) Calcitonin gene-related peptide potently stimulates glucagon-like peptide- 1 release in the isolated perfused rat ileum. Peptides 21, 431-437.

30. Tappenden KA \& McBurney MI (1998) Systemic short-chain fatty acids rapidly alter gastrointestinal structure, function, and expression of early response genes. Dig Dis Sci 43, 1526-1536.

31. Tappenden KA, Drozdowski LA, Thomson AB, et al. (1998) Short-chain fatty acid-supplemented total parenteral nutrition alters intestinal structure, glucose transporter 2 (GLUT 2) mRNA and protein, and proglucagon mRNA abundance in normal rats. Am J Clin Nutr 68, 118-125.

32. Drozdowski LA, Dixon WT, McBurney MI, et al. (2002) Short-chain fatty acids and total parenteral nutrition affect intestinal gene expression. JPEN 26, 145-150.

33. Karaki S, Tazoe H, Hayashi H, et al. (2008) Expression of the short-chain fatty acid receptor, GPR 43, in the human colon. J Mol Histol 39, 135-142.

34. Dumoulin V, Moro F, Barcelo A, et al. (1998) Peptide YY, glucagon-like peptide-1, and neurotensin responses to luminal factors in the isolated vascularly perfused rat ileum. Endocrinology 139, 3780-3786.

35. Hashimoto T, Lluis F, Gomez G, et al. (1991) Intracolonic fat inhibits gastric acid secretion independent of gastrin release in the dog. Dig Dis Sci 36, 888-892.

36. Date Y, Kojima M, Hosoda H, et al. (2000) Ghrelin, a novel growth hormone-releasing acylated peptide, is synthesized in a distinct endocrine cell type in the gastrointestinal tracts of rats and humans. Endocrinology 141, 4255-4261.

37. Sakata I, Nakamura K, Yamazaki M, et al. (2002) Ghrelinproducing cells exist as two types of cells, closed- and openedtype cells, in the rat gastrointestinal tract. Peptides 23, 531-536.

38. Erdmann J, Lippi F \& Schusdziarra V (2003) Differential effect of protein and fat on plasma ghrelin levels in man. Reg Peptides 116, $101-107$.

39. Schling P, Rudolph C, Heimerl S, et al. (2006) Expression of tumor necrosis factor $\alpha$ and its receptors during cellular differentiation. Cytokine 33, 239-245.

40. Hong Y-H, Nishimura Y, Hishikawa D, et al. (2005) Acetate and propionate short chain fatty acids stimulate adipogenesis via GPCR43. Endocrinology 146, 5092-5099.

41. Freeland KR, Wilson C \& Wolever TMS (2009) Adaptation of colonic fermentation and glucagon-like peptide-1 secretion with increased wheat fibre intake for 1 year in hyperinsulinaemic human subjects. Br J Nutr (epublication ahead of print version 7 August 2009).

42. Cummings JH, Hill MJ, Jenkins DJ, et al. (1976) Changes in fecal composition and colonic function due to cereal fiber. Am J Clin Nutr 29, 1468-1473.

43. Bridges SR, Anderson JW, Deakins DA, et al. (1992) Oat bran increases serum acetate of hypercholesterolemic men. Am $J$ Clin Nutr 56, 455-459.

44. Muir JG, Lu ZX, Young GP, et al. (1995) Resistant starch in the diet increases breath hydrogen and serum acetate in human subjects. Am J Clin Nutr 61, 792-799. 